\begin{tabular}{c} 
Brazilian Journal \\
of Chemical \\
Engineering \\
\hline
\end{tabular}

ISSN 0104-6632

Printed in Brazil

www.abeq.org.br/bjche

Vol. 32, No. 01, pp. 43 - 52, January - March, 2015

dx.doi.org/10.1590/0104-6632.20150321s00003124

\title{
RECOVERY OF CYCLODEXTRIN GLUCANOTRANSFERASE (CGTase) USING IMMOBILIZED METAL CHELATING AFFINITY CHROMATOGRAPHY
}

\author{
M. Sivapragasam ${ }^{1 *}$ and N. Abdullah ${ }^{2}$ \\ ${ }^{1}$ Industrial Biotechnology Laboratory, Institute of Biosciences, Universiti Putra Malaysia, Serdang 43400, Malaysia. \\ *E-mail: magaret_62@yahoo.co.uk \\ ${ }^{2}$ Department of Chemical \& Environmental Engineering, Universiti Putra Malaysia, Serdang 43400, Malaysia. \\ Phone: + 60389566295, Fax: +60386567120 \\ E-mail: nhafizah@upm.edu.my
}

(Submitted: November 18, 2013 ; Revised: May 4, 2014 ; Accepted: May 9, 2014)

\begin{abstract}
Immobilized metal affinity chromatography (IMAC) was chosen as a method of purification for the recovery of CGTase from E. coli homogenate. E. coli harbouring the Bacillus sp. G1 gene expressed extracellularly secreted CGTase into ampicillin supplied LB broth. Culture was pre-purified using SnakeSkin dialysis tubing (3.5 MWCO) with an enzyme activity of $147.80 \mathrm{U} / \mathrm{mL}$. Three strategies (A, B and C) were employed for the purification of CGTase using column adsorption chromatography with $\mathrm{Ni}^{2+}$-Sepharose resin. Strategy A employed an elution buffer of $50 \mathrm{mM}$ EDTA, pH 7, Strategy B used $0.1 \mathrm{M}$ imidazole, $\mathrm{pH} 7$ and Strategy $\mathrm{C}$ employed $45 \mathrm{mM}$ imidazole $\mathrm{pH} 7$ as the elution buffer. Strategy $\mathrm{C}$ was found to be most suitable yielding a total CGTase recovery of $87.04 \%$ from an initial activity of $147.80 \mathrm{U} / \mathrm{mL}$.

Keywords: Affinity chromatography; Binding capacity; CGTase; New chromatographic adsorbent; NickelSepharose chelating.
\end{abstract}

\section{INTRODUCTION}

Cyclodextrin glucanotransferase (CGTase) is a class of enzymes consisting of three subtypes namely $\alpha, \beta$ and $\gamma$-CGTase. They are monomeric enzymes that are secreted extracellularly and catalyze transglycosylation reactions via their glucosyl residues, which are used as an acceptor in forming cyclodextrins (CD). CD's are widely used in the pharmaceutical, medicine, food, textile, agriculture and the cosmetic industries. They have the unique property of solubilizing hydrophobic material and have the ability to entrap volatile compounds by forming inclusion complexes. Purifying CGTase is often a complicated task due to its heterogeneity, complexity and instability. obtaining it requires downstream proc- essing, which typically consist of a cascade of recovery steps. Current purification strategies include starch adsorption (Higuti et al., 2013, Atanasova et al., 2011, Kitayska et al., 2011, Vassileva et al., 2007, Yampayont et al., 2006 and Martins and Hatti-Kaul, 2002), $\alpha$ cyclodextrin bound epoxy-activated Sepharose 6B affinity chromatography (Goh et al., 2012, Guru et al., 2012, Qi et al., 2007, Rahman et al., 2006 and Sian et al., 2005), ion exchange chromatography (Ibrahim et al., 2012, Savergave et al., 2008, Alves-Prado et al., 2007 and Doukyu et al., 2003), hydrophobic interaction chromatography (Shetty et al., 2011 and Charoensakdi et al., 2007) and aqueous two-phase separation (Rosso et al., 2005).

Immobilised metal affinity chromatography is a type of purification method that exploits high-affin-

*To whom correspondence should be addressed 
ity coordination binding between a group of amino acids (such as histidines, cysteine and tryptophan), with divalent metal ions (such as $\mathrm{Zn}^{2+}, \mathrm{Cu}^{2+}, \mathrm{Ni}^{2+}$, $\mathrm{Co}^{2+}, \mathrm{Fe}^{3+}$ and $\mathrm{Ga}^{3+}$ ) chelated to IMAC ligands preimmobilised onto the resin (Ueda et al., 2003).

The IMAC interaction is based on the interaction of surface accessible side-chains of amino acid (mostly histidine) residues with the immobilized chelated metal ions on the resin (Westra et al., 2001). Various factors such as the nature of the chelating groups, metal ion, ligand density on the adsorbent, surface amino acid composition of the protein, molecular size and the surrounding environment (e.g., $\mathrm{pH}$, nature of buffer salts, ionic strength and temperature) affect protein adsorption in IMAC (Vunnum et al., 1995, Porath, 1992, Arnold, 1991). Advantages of IMAC include the ability of high protein loading, ligand stability, mild elution condition, low cost and simple regeneration and these have been intensively reviewed by several authors in the past (Yang et al., 2011, Prasanna et al., 2010, Gaberc-Porekar et al., 2001).

Based on the nature of the interactions between metal ions and proteins, the target proteins can be selectively eluted from IMAC resin by an elution buffer with either a suitable $\mathrm{pH}$ (via protein protonation) or an appropriate concentration of imidazole (competitive chelator). Some elution protocols also usedstrong chelating compounds, such as EDTA, urea, or guanidine hydrochloride to elute proteins with a strong affinity for IMAC (Sun et al., 2005). Most CGTase variants are known to contain approximately 10 histidine residues in their primary structure. In previous studies, (Volkova et al., 2000) and (Cristancho et al., 2013) described the application of IMAC resin for the purification of CGTase and found this approach to be simple, effective, high capacity, reproducible, stable and cost effective. In order to achieve higher selectivity and efficiency in IMAC separation, it is essential to understand the interaction between adsorbate and adsorbent during binding, washing and elution. Purification of CGTase was performed using $\mathrm{Ni}^{2+}$-Sepharose. $\mathrm{Ni}^{2+}$ seemed to be the most suitable in terms of selectivity for distribution of the histidine residues on the protein surface (Dalal et al., 2008) and it is important to choose first-row transition metal ions $\left(\mathrm{Cu}^{2+}, \mathrm{Ni}^{2+}\right.$, $\mathrm{Co}^{2+}$ and $\mathrm{Zn}^{2+}$ ) (Clemmitt et al., 2000).

Concentration of salt and the $\mathrm{pH}$ of the buffer used for loading, washing and elution in the purification of CGTase have to be properly formulated. A well-defined binding/elution condition is crucial to enhance the purification performance and yield, while reducing the overall operation cost. In this study, the efficiency of immobilised metal affinity chromatography was assessed in the recovery of CGTase from $E$. coli homogenate.

\section{MATERIALS AND METHODS}

\section{Organism and Culture Conditions of CGTase}

The alkalophilic bacteria Bacillus sp G1 was originally isolated from soil. CGTase was isolated and inserted into E. coli BL21 as per (Goh et al., 2008). The recombinant strain was then grown in Luria-Bertani broth supplemented with $50 \mu \mathrm{g} / \mathrm{mL}$ ampicillin (CALBIOCHEM, Massachusetts, USA). Upon harvesting and centrifugation, the supernatant was used as crude enzyme for the subsequent prepurification steps.

\section{Pre-Concentration of CGTase from $E$. coli Feed- stock Via Snakeskin Dialysis Tubing}

Twenty $\mathrm{ml}$ of $E$. coli feedstock supernatant containing CGTase was dialyzed against $100 \mathrm{mM}$ sodium phosphate buffer, $\mathrm{pH}$ 7, in a SnakeSkin (Thermo Scientific, Illinois, USA) dialysis tube having an internal diameter of $3.5 \mathrm{~cm}$. Experiments were performed at $4{ }^{\circ} \mathrm{C}$ in an ice bath overnight under gentle mixing. Pre-concentrated CGTase was used for subsequent purification steps.

\section{Preparation of $\mathrm{Ni}^{2+}$ Loaded Sepharose Chelating Resin}

Sepharose chelating resin (particle size of 45-165 $\mu \mathrm{M})$ (GE Healthcare, Uppsala, Sweden) slurry was prepared in distilled water at a ratio of $75 \%$ settled resin volume to $25 \%$ distilled water. Adsorption was performed by mixing $30 \mathrm{~mL}$ of an aqueous solution containing $50 \mathrm{mM}$ of nickel chloride $(\mathrm{pH} 5.5)$ with $15 \mathrm{ml}$ of IMAC Sepharose resin (GE Healthcare, Uppsala, Sweden) and left to mix on the rotator for 24 hours.

\section{Column Preparation}

Prepared resin was packed into the Tricorn 10/50 column and assembled accordingly. The column containing the $\mathrm{Ni}^{2+}$ chelated Sepharose resin was washed with $5 \mathrm{CV}(19.6 \mathrm{~mL})$ of distilled water to remove excess metal ions. The column was then subsequently washed with $20 \mathrm{mM}$ sodium acetate buffer, $\mathrm{pH} \mathrm{5}$, to elute loosely bound ions that might leak out during a the chromatographic run. For equilibration, $5 \mathrm{CV}(19.6 \mathrm{~mL})$ of the binding buffer (20 mM sodium phosphate buffer, $\mathrm{pH}$ 7) was 
pumped through the bed prior to the loading of the CGTase feedstock.

Static Binding Capacity of CGTase Onto $\mathrm{Ni}^{2+}-$ Sepharose IMAC Resin Using an Adsorption Isotherm Model

To each series of tubes, clarified CGTase solutions at concentrations of $0-100 \%$ were prepared by dilution in $20 \mathrm{mM}$ sodium phosphate buffer, $\mathrm{pH} 7$. $200 \mu \mathrm{L}$ of $\mathrm{Ni}^{2+}$ loaded IMAC resin were added to each tube at a 50:50 slurry ratio. Each tube was sealed and mixed end over end using a rotator for 2 hours at room temperature, $20^{\circ} \mathrm{C}$. The initial enzyme activity and protein assays were performed. After 2 hours, all the tubes were removed and centrifuged to allow settling. Clarified supernatants were collected and assayed for remaining total protein and enzyme activity.

\section{Dynamic Binding Capacity of CGTase Onto $\mathrm{Ni}^{2+}$ Sepharose IMAC Resin}

The $\mathrm{Ni}^{2+}$-Sepharose IMAC resin packed in a Tricorn 10/50 column was equilibrated with $5 \mathrm{CV}$ $(19.6 \mathrm{~mL})$ of washing buffer, which was sufficient to achieve the target $\mathrm{pH}$ and conductivity. Protein was loaded onto the resin until breakthrough was observed based on absorbance at $280 \mathrm{~nm}\left(A_{280}\right)$. Unbound protein was washed with $5 \mathrm{CV}(19.6 \mathrm{~mL})$ of washing buffer ( $20 \mathrm{mM}$ sodium phosphate buffer, $\mathrm{pH}$ 7). All experiments were conducted at ambient temperature $\left(25-27^{\circ} \mathrm{C}\right)$ and a flow rate of $100 \mathrm{~cm} / \mathrm{h}$, corresponding to a residence time of $6 \mathrm{~min}$.

Column Purification of CGTase Via Packed Bed Adsorption Approach Using $\mathrm{Ni}^{2+}-$ Sepharose IMAC Resin

All buffers were filtered prior to use through 0.2 $\mu \mathrm{m}$ Whatman filter paper with a vacuum pressure pump. A Tricorn 10/50 column (GE Healthcare, Uppsala, Sweden) was loaded with IMAC resin and attached to fast protein liquid chromatography (FPLC) (GE Healthcare, Uppsala, Sweden) equipment. A settled column of $\mathrm{Ni}^{2+}$-Sepharose loaded IMAC resin was equilibrated with $20 \mathrm{mM}$ sodium phosphate buffer, $\mathrm{pH} \mathrm{7}$, at a flow rate of $1.00 \mathrm{~mL} / \mathrm{min} .20 \mathrm{~mL}$ of clarified CGTase was injected once the baseline at $\mathrm{A}_{280}$ was observed. Non-bound protein was washed from the resin bed with $25 \mathrm{~mL}$ of $20 \mathrm{mM}$ sodium phosphate buffer, $\mathrm{pH} 7$. Elutions were performed via 3 methods. Elution buffers used were: $20 \mathrm{mM}$ sodium phosphate buffer, $50 \mathrm{mM}$ EDTA, $\mathrm{pH} 7$ (gradient elution); $20 \mathrm{mM}$ sodium phosphate buffer, $1 \mathrm{M}$ imidazole, $\mathrm{pH} 7$ (gradient elution); and $20 \mathrm{mM}$ sodium phosphate buffer, $450 \mathrm{mM}$ imidazole, $\mathrm{pH} 7$ (single step elution). Eluents from experiments were collected every one $\mathrm{mL}$ and assayed for enzyme activity and protein concentration.

\section{Total Protein Determination}

Protein concentration was quantified according to the Bradford assay (Bradford, 1976) with bovine serum albumin (BSA) as a standard (PIERCE, Illinois, USA). For the calibration of the standard curve, $2 \mathrm{mg} / \mathrm{mL}$ of BSA was prepared in aliqouts. To $20 \mu \mathrm{L}$ of the protein sample, $1 \mathrm{~mL}$ of Bradford dye reagent was added and was incubated at room temperature for $5 \mathrm{~min}$ in a $1 \mathrm{~mL}$ cuvette. The absorbance reading was then taken at $595 \mathrm{~nm}$. A standard curve with various BSA (Sigma Aldrich, Misouri, USA) concentrations was generated and then employed to interpolate the protein concentration of unknown samples.

\section{CGTase Enzyme Assay}

CGTase activity was determined using the phenolphthalein assay as described by Kaneko et al., (1987). The assay was performed by adding $0.1 \mathrm{~mL}$ of the sample to CGTase assay reagent containing $1 \mathrm{~mL}$ of $0.04 \mathrm{~g}$ soluble starch in $0.1 \mathrm{M}$ phosphate buffer, $\mathrm{pH}$ 6.0. The mixture was then incubated at $60{ }^{\circ} \mathrm{C}$ for $10 \mathrm{~min}$. The reaction was stopped by adding $3.5 \mathrm{~mL}$ of $30 \mathrm{mM} \mathrm{NaOH}$ (Sigma Aldrich, Misouri, USA) followed by $0.5 \mathrm{~mL}$ of $0.02 \%(\mathrm{w} / \mathrm{v})$ phenolphthalein in $5 \mathrm{mM} \mathrm{Na}_{2} \mathrm{CO}_{3}$ (Sigma Aldrich, Misouri, USA). This mixture was mixed using a rotator mixer for 15 min (STUART SB2, Fisher Scientific, Pittsburgh, USA). The reduction in colour intensity was measured at $550 \mathrm{~nm}$. Blanks lacking the CGTase were analysed simultaneously with each batch of samples. One unit of enzyme activity was defined as the amount of enzyme that formed $1 \mu \mathrm{mol} \beta-\mathrm{CD}$ (Sigma Aldrich, Misouri, USA) per minute under the defined conditions.

\section{RESULTS AND DISCUSSION}

Static Binding Capacity of CGTase from $E$. coli Homogenate on the $\mathrm{Ni}^{2+}$-Sepharose IMAC Resin Using an Adsorption Isotherm Analysis

Tubes with clarified CGTase weres diluted with $20 \mathrm{mM}$ sodium phosphate buffer, $\mathrm{pH} 7$, in a range of $0-100 \%$. $\mathrm{Ni}^{2+}$-Sepharose resin was added with a $50: 50$ 
resin to slurry ratio. Tubes were then subjected to rotational agitation for 2 hours. Figure 1 represents the graph of experimental data for the equilibrium isotherm of CGTase on $\mathrm{Ni}^{2+}$ IMAC adsorbent and the least squares fit to the Langmuir equation. The obtained $q_{m}$ was $666.67 \mathrm{U} / \mathrm{mL} /$ and the $K_{d}$ was $5.3 \times 10^{-1}$ $\mathrm{U} / \mathrm{mL}$ (Figure 1). The graph depicts a slow approach towards equilibrium with non-steep initial slopes. Values obtained from this study were seen to be higher in comparison to (Dalal et al., 2008) who obtained $q_{m}$ values of $56.2 \mathrm{U} / \mathrm{mL} /$ resin and a $K_{d}$ values of 21.7 $\mathrm{M}$ when adsorption values were tested for green fluorescent protein (GFP) on $\mathrm{Ni}^{2+}$-STREAMLINE. Sharma et al. (2001) obtained higher $K_{d}\left(2 \times 10^{-5} \mathrm{M}\right)$ but lower $q_{m}$ values $(116-131 \mathrm{U} / \mathrm{mL})$ when the adsorption of model proteins, such as lysozyme, ovalbumin and conalbumin on $\mathrm{Ni}^{2+}$-IDA was studied.

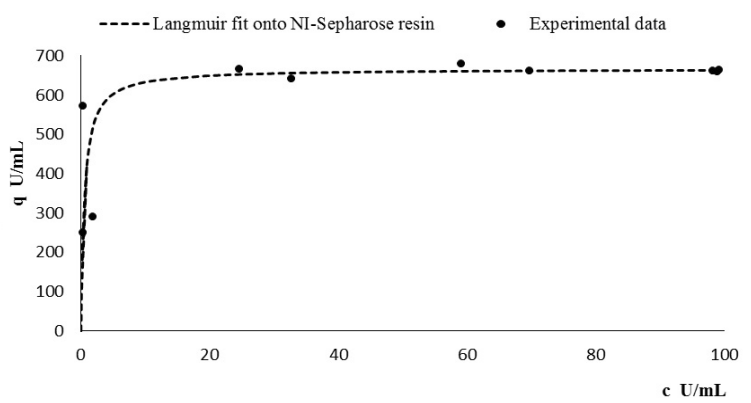

Figure 1: Graph of experimental data of the equilibrium isotherm of CGTase on $\mathrm{Ni}^{2+}$-Sepharose IMAC adsorbent.

During an IMAC adsorption process, various interactions may take place, which includes, in this case, non-specific binding. The lower $q m$ obtained could have been due to non-specific hydrophobic interactions that took place between the IMAC-Ni ${ }^{2+}$ Sepharose and the CGTase (Bornhorst et al., 2000). Considering the physical properties of the enzyme CGTase, the isoletric point is 6.5 (carrying a net negative charge at $\mathrm{pH}>6.5$ and a net positive charge at $\mathrm{pH}<6.5)$. The buffer involved ( $20 \mathrm{mM}$ PBS) is at the $\mathrm{pH}$ 7. The ligand $\mathrm{Ni}^{2+}$ is also positively charged. This thus creates a slight negative charge on the surface of the enzyme. A slight ion exchange interaction might have happened, causing the monolayer on the surface of the adsorbent to constantly change, hence explaining a slight deviation from Langmuirian principles, as seen in Figure 1. Foo et al. (2010) reported that, for metal binding, a linearized equation such as the Langmuir isotherm, generated problems and faults. These arise from the complex transformation of data, which leads to the violation of the funda- mentals underlying the Langmuir isotherm. However, among the many isotherm models, the Langmuir model stands as the most frequently used due to its simplicity (Yang et al., 2011), though said to be not suitable in the case of IMAC purification due to factors such as the formation of multiple coordination bonds and low capacities of IMAC resins to bind to protein (Tsai et al., 2006, Vunnum et al., 1995). Although there are many arguments for the use of a Langmuir adsorption isotherm system in an IMAC operation, this model has been successfully used to describe the binding of protein onto resins (Dalal et al., 2008, Tsai et al., 2006, Hasar, 2003, Finette et al., 1997).

\section{Dynamic Binding Capacity (DBC) of CGTase on $\mathrm{Ni}^{2+}$-Sepharose IMAC Resins Via Column Adsorp- tion Chromatography}

The DBC of CGTase on $\mathrm{Ni}^{2+}$-Sepharose was determined at $10 \%$ breakthrough. Clarified CGTase was loaded onto a Tricorn 10/50 column pre-packed with $3.92 \mathrm{ml}$ of $\mathrm{Ni}^{2+}$-Sepharose resin. CGTase was loaded at $1 \mathrm{ml} / \mathrm{min}$ until a breakthrough $\left(\mathrm{A}_{280}\right)$ was observed. DBC values were $6.43 \mathrm{mg} / \mathrm{ml}$ as seen in Figure 2. This value is coherent with results obtained by Bolanos-Garcia and Davies (2006) when purifying native proteins from $E$. coli using IMAC resin, who mentioned that $\mathrm{DBC}$ values of IMAC resins are within the range of $5-10 \mathrm{mg} / \mathrm{mL}$. Results from this study were superior to those obtained by Clemmitt et al. (2000), who purified $\beta$-galactosidase from $E$. coli homogenate (via an expanded bed adsorption) with DBC values of $0.78 \mathrm{mg} / \mathrm{mL}$. In another study of purification of histidine-tagged nucleocapsid protein of Nipah virus via IMAC (Chong et al., 2009), a DBC value of $2.5 \mathrm{mg} / \mathrm{ml}$ was obtained using Nickel Sepharose FF, which was also lower compared to this study. Deviations such as these were explained

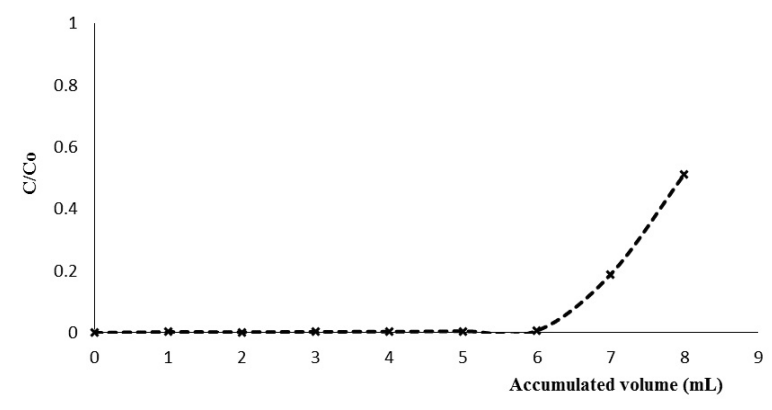

Figure 2: Breakthrough curve of CGTase on the $\mathrm{Ni}^{2+}$-Sepharose IMAC resin. 
by Sharma et al. (2001) as being due to the suitability or deviation of the interaction of the protein with the resin, which depends heavily on the nature of the protein. One disadvantage associated with the IMAC is its vulnerability to potential binding interference by metal chelating species that sometimes are present in cell cultures. The consequences include a pronounced reduction in protein binding efficiency and leakage of immobilized ions from the packed column during a chromatographic run (Zhang et al., 2011).

Purification of CGTase from $E$. coli Homogenate Using $\mathrm{Ni}^{2+}$-Sepharose IMAC Resin Loaded in a Packed Bed Adsorption Column Chromatography

Purification of CGTase from E. coli homogenate using $\mathrm{Ni}^{2+}$-Sepharose IMAC resin was performed using three elution strategies which are:

Strategy A: Elution buffer: $20 \mathrm{mM}$ sodium phosphate buffer, $50 \mathrm{mM}$ EDTA, pH 7 (gradient elution);

Strategy B: Elution buffer: $20 \mathrm{mM}$ sodium phosphate buffer, $0.1 \mathrm{M}$ imidazole, pH 7 (gradient elution);

Strategy C: Elution buffer: $20 \mathrm{mM}$ sodium phosphate buffer, $45 \mathrm{mM}$ imidazole, $\mathrm{pH} 7$ (single step elution).

\section{Elution of Bound CGTase on $\mathrm{Ni}^{2+}$-Sepharose IMAC Resin Via Strategy A}

Twenty $\mathrm{ml}$ of clarified E. coli homogenate containing the enzyme CGTase was loaded onto a packed column of $\mathrm{Ni}^{2+}$-Sepharose resin. The column was then equilibrated and washed with $25 \mathrm{ml}$ of $20 \mathrm{mM}$ PBS, $\mathrm{pH} 7$, with a fixed flow rate of $1 \mathrm{~mL} / \mathrm{min}$ throughout. Once unbound protein was removed from the column, bound proteins were eluted via $20 \mathrm{mM}$ PBS, $50 \mathrm{mM}$ EDTA, $\mathrm{pH}$ 7. This was performed via a $0-50 \mathrm{mM}$ gradient elution with $20 \mathrm{mM}$ PBS, $\mathrm{pH} 7$, and $20 \mathrm{mM}$ PBS, $50 \mathrm{mM}$ EDTA, $\mathrm{pH} 7$.

From the chromatogram (Figure 3), $20 \mathrm{~mL}$ of feedstock containing the CGTase enzyme were loaded onto the Tricorn 10/50 column containing the $\mathrm{Ni}^{2+}$-Sepharose IMAC resin. About 20\% enzyme loss was observed during the flowthrough step (Table 1). Protein concentrations $(\mathrm{mg} / \mathrm{mL})$ followed closely the enzyme activity $(\mathrm{U} / \mathrm{mL})$. A further $13 \%$ enzyme loss was observed during the washing step using the buffer of $20 \mathrm{mM}$ PBS, $\mathrm{pH}$ 7. The elution buffer, 20 $\mathrm{mM}$ PBS, $50 \mathrm{mM}$ EDTA, $\mathrm{pH}$ 7, was applied in a gradient manner from 0-50 mM EDTA. This was achieved using two buffers, $20 \mathrm{mM}$ PBS, $\mathrm{pH}$ 7, and $20 \mathrm{mM}$ PBS-50 mM EDTA, $\mathrm{pH}$ 7. The elution buffer were applied gradiently for $40 \mathrm{~mL}$ and resulted in an overall enzyme yield of $45 \%$. The elution step gave a 1.01 -fold purification relative to the initial feedstock.

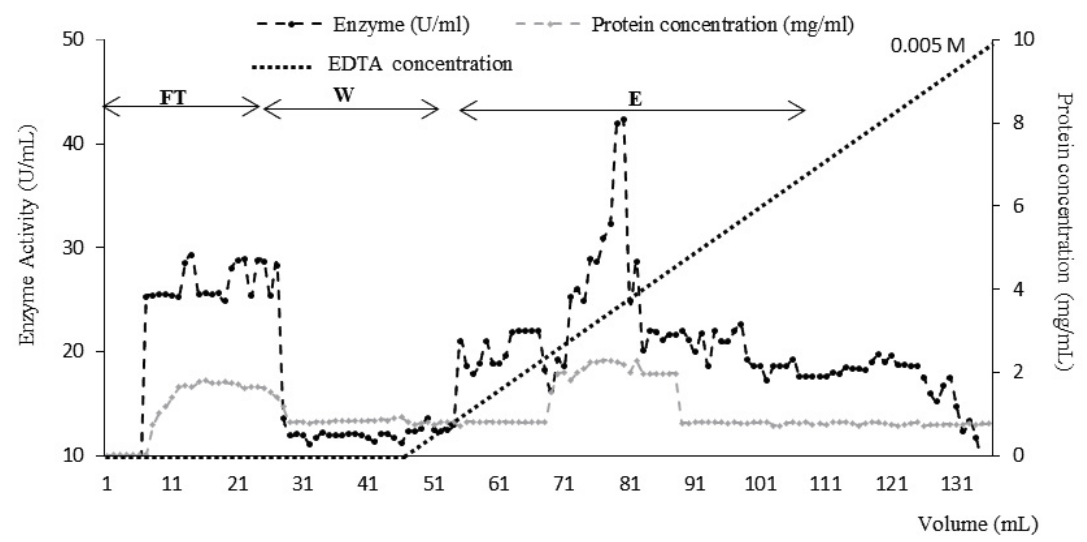

Figure 3: Chromatogram of CGTase separation via $\mathrm{Ni}^{2+}-$ Sepharose IMAC resin at $1 \mathrm{~mL} / \mathrm{min}$. Buffers used: equilibration buffer: $20 \mathrm{mM}$ sodium phosphate, $\mathrm{pH}$ 7, washing buffer: $20 \mathrm{mM}$ sodium phosphate buffer, pH7, gradient elution $20 \mathrm{mM}$ sodium phosphate, 50mM EDTA, pH 7.

Table 1: Purification table for CGTase using $\mathrm{Ni}^{2+}$-Sepharose IMAC resin. (Strategy A).

\begin{tabular}{|l|c|c|c|c|c|c|}
\hline Purification stage & $\begin{array}{c}\text { Volume } \\
(\mathbf{m l})\end{array}$ & $\begin{array}{c}\text { Total Activity } \\
(\mathbf{U})\end{array}$ & $\begin{array}{c}\text { Total Protein } \\
(\mathbf{m g})\end{array}$ & $\begin{array}{c}\text { Specific activity } \\
(\mathbf{U} / \mathbf{m g})\end{array}$ & $\begin{array}{c}\text { Fold } \\
\text { Yield } \\
(\%)\end{array}$ \\
\hline Clarified homogenate & 20 & 2956 & 77.6 & 38.09 & 1. & 100 \\
Flowthrough & 20 & 573 & 21.4 & 26.78 & 0.7 & 19 \\
Washing & 25 & 370 & 17.75 & 20.85 & 0.55 & 13 \\
Elution & 50 & 1325.6 & 34.4 & 38.53 & 1.01 & 45 \\
\hline
\end{tabular}


With every IMAC column, some leaching of metal ions occurs, depending on the type of chelating compound involved and the sort of elution. To assess this phenomenon, the elution samples collected during the elution peak were subjected to nickel ion leaching analysis using an inductively coupled plasmamass spectrometer (ICP-MS). For the effluent using $50 \mathrm{mM}$ EDTA buffer, very high $\mathrm{Ni}^{2+}, 158 \mathrm{mg} / \mathrm{L}$, was co-eluted in the elution step. Metal leaching may generate charged groups which act as a cation exchanger and bind to the positively charged groups on the surface of the proteins (Block et al., 2009) which accounts for low CGTase yields. $\mathrm{Ni}^{2+}$ compounds are also established human carcinogens (Kozlowski et al., 2000) and thus must be removed from the final product. Although the role of $\mathrm{Ni}^{2+}$ in carcinogenesis is not clear, some molecular models suggest interaction with histones in the cell nucleus, leading to DNA damage. Application of a strong chelating agent, such as EDTA, resulted in co-elution of the bound proteins. Elution with EDTA was also found to cause a co-elution of a small amount of enzyme before and after the main peak (Figure 3). This could also be due to the distribution of histidine residues on the surface of CGTase. Hemdan et al. (1989) mention that locations of histidines residues is critical for the exploitation of IMAC chromatography. These histidine residues could be on the surface or interior, localized, accessible or non-accessible for coordination, distant or vicinal. Sometimes intramolecular interaction such as hydrogen bonding may also occur, which results in a non-attachment of the histidine to the $\mathrm{Ni}^{2+}$-Sepharose resin. Thus, the EDTA was too strong as a chelating compound and eluted most of the $\mathrm{Ni}^{2+}$ ion from $\mathrm{Ni}^{2+}$-Sepharose IMAC resin. A second competitive agent, imidazole, was therefore chosen to replace EDTA in the elution buffer.

\section{Elution of Bound CGTase on $\mathrm{Ni}^{2+}$-Sepharose IMAC Resin Via Strategy B}

Twenty $\mathrm{mL}$ of clarified E. coli homogenate containing the enzyme CGTase was loaded onto a packed column containing $\mathrm{Ni}^{2+}$-Sepharose resin. The column was then equilibrated and washed with $25 \mathrm{ml}$ of $20 \mathrm{mM}$ PBS, $\mathrm{pH}$ 7, with a flow rate of $1 \mathrm{~mL} / \mathrm{min}$. Once unbound protein was removed from the column, bound proteins were eluted via $20 \mathrm{mM}$ PBS, $\mathrm{pH} 7,0.1 \mathrm{M}$ imidazole. This was performed via a 0$100 \mathrm{mM}$ gradient elution with $20 \mathrm{mM}$ PBS, $\mathrm{pH} 7$, and $20 \mathrm{mM}$ PBS, $0.1 \mathrm{M}$ imidazole, $\mathrm{pH} 7$.

From the chromatogram in Figure 4, about 30\% enzyme loss was observed in the flowthrough step (Table 2). In the washing step, a 13\% enzyme loss was noted. This was the same as the results obtained when using the same washing buffer (20 mM PBS, $\mathrm{pH} 7$ ) in the earlier purification step (Strategy A). The elution buffer used was $20 \mathrm{mM}$ PBS, $\mathrm{pH} 7,0.1 \mathrm{M}$ imidazole. This was applied in a gradient manner using two buffers, i.e., $20 \mathrm{mM}$ PBS, pH 7, and $20 \mathrm{mM}$ PBS, $0.1 \mathrm{M}$ imidazole, $\mathrm{pH}$ 7. Yields of $57 \%$ enzyme were obtained, which were higher than that obtained using Strategy A (0.05 M EDTA as chelating agent) with a $45 \%$ elution yield. However, a similar chromatogram pattern (Figure 3 and Figure 4) with the formation of "shoulder" peaks (elution before and after the main peak) was observed, which resulted in a large amount of buffer loss. An apparent peak was observed at $45 \mathrm{mM}$ imidazole concentration (Figure 4). It indicated that most of the elution occurred at $45 \mathrm{mM}$ imidazole, which is more cost effective. Hence to reduce cost, buffer loss and the harmful effects of this chelating agent, subsequent elutions were done at $45 \mathrm{mM}$ of imidazole in a single step manner.

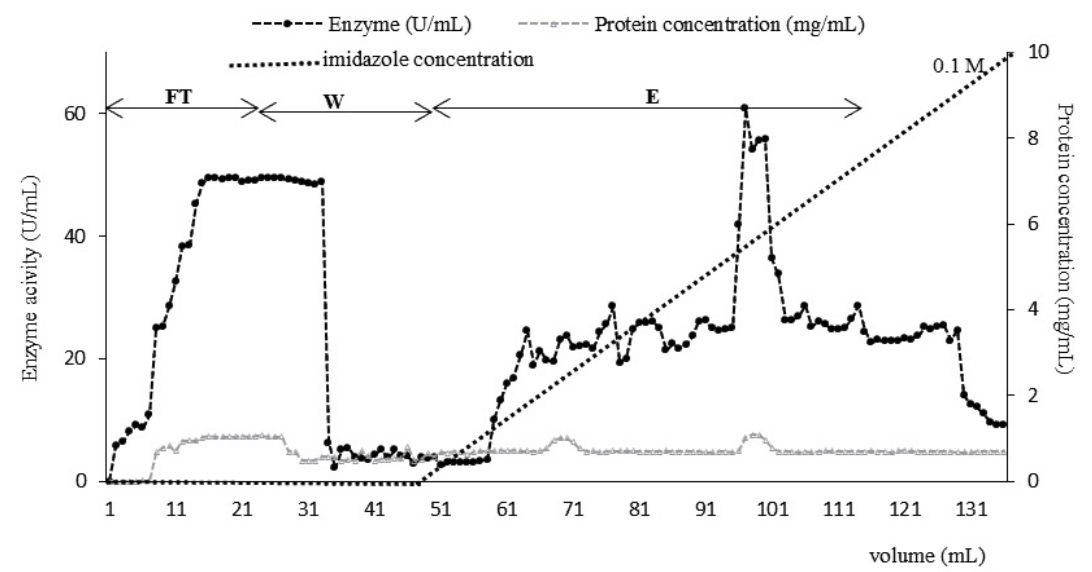

Figure 4: Chromatogram of CGTase separation via $\mathrm{Ni}^{2+}$ IMAC resin at $1 \mathrm{~mL} / \mathrm{min}$. Buffers used: equilibration buffer: $20 \mathrm{mM}$ sodium phosphate, $\mathrm{pH}$ 7, washing buffer: $20 \mathrm{mM}$ sodium phosphate buffer, $\mathrm{pH} 7$, gradient elution $20 \mathrm{mM}$ sodium phosphate, $0.1 \mathrm{M}$ Imidazole, $\mathrm{pH} 7$. 
Table 2: Purification table for CGTase using $\mathrm{Ni}^{2}$-Sepharose IMAC resin (Strategy B).

\begin{tabular}{|l|c|c|c|c|c|c|}
\hline Purification stage & $\begin{array}{c}\text { Volume } \\
(\mathbf{m l})\end{array}$ & $\begin{array}{c}\text { Total activity } \\
(\mathbf{U})\end{array}$ & $\begin{array}{c}\text { Total protein } \\
(\mathbf{m g})\end{array}$ & $\begin{array}{c}\text { Specific activity } \\
\text { (U/mg) }\end{array}$ & Fold & Yield (\%) \\
\hline Clarified homogenate & 20 & 2956 & 77.6 & 38.09 & 1 & 100 \\
Flowthrough & 20 & 885.33 & 19.4 & 45.64 & 1.2 & 30 \\
Washing & 25 & 371.25 & 14.33 & 25.91 & 0.68 & 13 \\
Elution & 50 & 1684.25 & 51.5 & 32.7 & 0.86 & 57 \\
\hline
\end{tabular}

\section{Elution of Bound CGTase on $\mathrm{Ni}^{2+}$-Sepharose IMAC Resin Via Strategy C}

Twenty $\mathrm{mL}$ of clarified $E$. coli homogenate containing the enzyme CGTase was loaded onto a packed column containing $\mathrm{Ni}^{2+}$-Sepharose resin. The column was then equilibrated and washed with $25 \mathrm{ml}$ of $20 \mathrm{mM}$ PBS, $\mathrm{pH}$ 7, with a flow rate of $1 \mathrm{~mL} / \mathrm{min}$. Once unbound protein was removed from the column, bound proteins were eluted via $20 \mathrm{mM}$ PBS, $0.045 \mathrm{M}$ imidazole, $\mathrm{pH}$ 7. This was performed via a single step elution.

The chromatogram in Figure (5) presented a good IMAC separation. A single step elution was done using $45 \mathrm{mM}$ imidazole throughout. Purification of CGTase performed with $45 \mathrm{mM}$ imidazole as its elution buffer showed a 5-fold purification during the elution step with yields of $49 \%$ (Table 3 ). The loss of enzyme was $13 \%$, which indicated a good separation by $\mathrm{Ni}^{2+}$-Sepharose IMAC resin. The remaining enzyme in the $\mathrm{Ni}^{2+}$-Sepharose IMAC column was regenerated by washing the column with 50 mM EDTA.

In the past, only two studies of the purification of CGTase using metal affinity chromatography were performed. In the first study by Berna et al. (1996), the enzyme CGTase was purified in a single step metal affinity chromatography using two metals $\mathrm{Cu}$ (II), $\mathrm{Zn}$ (II) and a tandem combination of $\mathrm{Cu}$ (II) and $\mathrm{Zn}$ (II). $25 \mathrm{mM}$ imidazole was used as the eluting agent coupled with $50 \mathrm{mM}$ EDTA. When using the tandem combination of $\mathrm{Cu}$ (II) and $\mathrm{Zn}$ (II) there were no deleterious effects on enzyme activity. IMAC was demonstrated to be a viable technique that can outperform biospecific affinity chromatography (such as $\beta$-CD). This is because metal affinity chromatography gives similar purity and activity recovery with minimal or no additional steps required, which is an additional advantage when it comes to industrial applications. In the second study by Volkova et al. (2000), CGTase was purified using $\mathrm{Cu}$ (II)-IDAAgarose and desorbed with the addition of $25 \mathrm{mM}$ of imidazole to the washing buffer in a single step elution manner. The specific activity of the CGTase increased 15 -fold in comparison to the initial value $(273.6 \mathrm{U} / \mathrm{mL})$. Results showed a $73 \%$ activity recovery, which is lower that than obtained from this study ( $87 \%$ ). The author suggested the use of IMAC because most of the CGTases are said to contain approximately 10 histidine residues in their primary structure. The affinity of CGTase to $\mathrm{Cu}$ (II)-IDAAgarose is based on the coordination bond formation between the metal ion and the imidazole groups of the accessible histidine groups in the primary structure

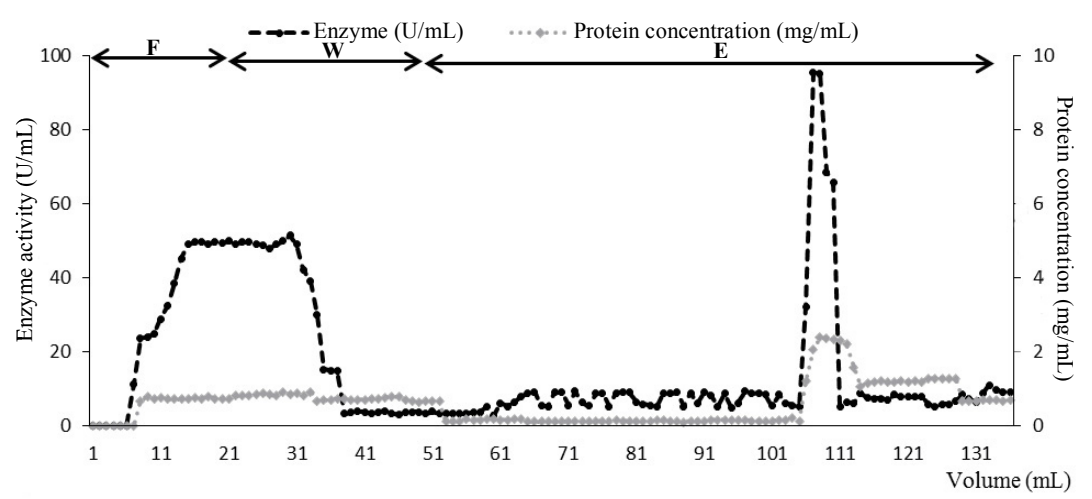

Figure 5: Chromatogram of CGTase separation via $\mathrm{Ni}^{2+}$ IMAC resin at $1 \mathrm{~mL} / \mathrm{min}$. Buffers used: equilibration buffer: $20 \mathrm{mM}$ sodium phosphate, $\mathrm{pH}$ 7, washing buffer: $20 \mathrm{mM}$ sodium phosphate buffer, $\mathrm{pH} 7$, single step elution $20 \mathrm{mM}$ sodium phosphate, $45 \mathrm{mM}$ Imidazole, $\mathrm{pH} 7$. 
Table 3: Purification table for CGTase using $\mathrm{Ni}^{2+}$-Sepharose IMAC resin (Strategy C).

\begin{tabular}{|l|c|c|c|c|c|c|}
\hline Purification stage & $\begin{array}{c}\text { Volume } \\
(\mathbf{m l})\end{array}$ & $\begin{array}{c}\text { Total activity } \\
(\mathbf{U})\end{array}$ & $\begin{array}{c}\text { Total protein } \\
(\mathbf{m g})\end{array}$ & $\begin{array}{c}\text { Specific activity } \\
\text { (U/mg) }\end{array}$ & $\begin{array}{c}\text { Fold } \\
\text { Yield } \\
\mathbf{( \% )}\end{array}$ \\
\hline Clarified homogenate & 20 & 2956 & 77.6 & 38.09 & 1. & 100 \\
Flowthrough & 20 & 870.6 & 15.4 & 56.53 & 1.48 & 30 \\
Washing & 25 & 411.14 & 19 & 21.64 & 0.57 & 14 \\
Elution & 80 & 1291.2 & 7.5 & 172.16 & 4.52 & 45 \\
\hline
\end{tabular}

Total enzyme recovery: $87.04 \%$

(Volkova et al., 2000). The enzyme is also said to be metal-independent since activity was retained with EDTA, but inhibition with $\mathrm{Zn}^{2+}, \mathrm{Ni}^{2+}, \mathrm{Cu}^{2+}$ and $\mathrm{Fe}^{3+}$ indicated the presence of histidine residues. In another study by Clemmitt et al. (2000), single step elutions were studied using various imidazole concentrations for the purification of green fluorescent protein (GFP) via an IMAC expanded bed adsorption. Imidazole with single step elution was found to yield a better separation and higher enzyme yields.

The ICP results showed only $0.4512 \mathrm{mg} / \mathrm{L}$ nickel ion was co-eluted with the CGTase. This amount of nickel is considered insignificant $(<0.5 \mathrm{ppm})$ and proved that $20 \mathrm{mM}$ sodium phosphate with $45 \mathrm{mM}$ of imidazole, $\mathrm{pH} 7$, was a suitable elution buffer.

\section{CONCLUSION}

The equilibrium binding capacity of CGTase toward $\mathrm{Ni}^{2+}$ IMAC resin was high, $666.67 \mathrm{U} / \mathrm{mL}$, and the dissociation constant is $5.3 \times 10^{-1} \mathrm{U} / \mathrm{mL}$ This indicated a strong binding capacity and affinity of the $\mathrm{Ni}^{2+}$ IMAC resin towards the enzyme. The dynamic binding capacity was $6.43 \mathrm{mg} / \mathrm{mL}$ of resin. The separation using $45 \mathrm{mM}$ imidazole in the elution buffer gave 4.5 -fold purification during the elution step and an $87 \%$ overall recovery of CGTase. Moreover, the nickel ion concentration in the eluted sample was only $0.4512 \mathrm{mg} / \mathrm{L}$, which is approved for usage in the cosmetic and textile industry. All in all, IMAC separation has proven to be reliable, efficient and inexpensive in our preparatory scale test. It played an important role in reducing metal leaching into the final product, achieving higher purification and avoiding the denaturing of the enzyme during the process.

\section{REFERENCES}

Alves-Prado, H. F., Gomes, E., Silva, R., Purification and characterization of a cyclomaltodextrin glucanotransferase from Paenibacillus campinasensis strain H69-3. Appl. Biochem. Biotechnol., 136-140, 41-56 (2007).

Arnold, F. H., Metal-affinity separations: A new dimension to protein processing. Biotechnol., 9, 151-156. (1991).

Atanasova, N., Kitayska, T., Bojadjieva, I., Yankov, D., Tonkova, A., A novel cyclodextrin glucanotransferase from alkaliphilic Bacillus pseudalcaliphilus 20RF: Purification and properties. Process Biochem., 46, 116-122 (2011).

Avci, A., Dönmez, S., Purification and characterization of a thermostable cyclodextrin glycosyltransferase from Thermoanaerobacter sp. P4. Afr. J. Biotechnol., 11(45), 10407-10415 (2012).

Berna, P., Moraes, F. F., Barbotin, J. N., Thomas, D. and Vijayalakshmi, M. A., One step affinity purification of a recombinant cyclodextrin glycosyl transferase by ( $\mathrm{Cu}(\mathrm{II}), \mathrm{Zn}$ (II) tandem column) immobilized metal-ion affinity chromatography. Adv. Mol. Cell Biol., 15, 523-537 (1996).

Block, H., Maertens, B., Spriestesbach, A., Brinker, N., Kubicek, J., Fabis, R., Labahn, J., Schäfer, F., Immobilised metal affinity chromatography (IMAC): A review. Met. Enzymol., 463, 439-473 (2009).

Bolanos-Garcia, V. M., Davies, O. R., Structure analysis and classification of native proteins from $E$. coli commonly co-purified by immobilised metal affinity chromatography. Biochim. Biophys. Acta, 1760 (9), 1304-1313 (2006).

Bornhorst, J. A., Falke, J. J., Purification of proteins using polyhistidine affinity tags. Met. Enzymol., 326, 245-254 (2000).

Bradford, M. M., A rapid and sensitive method for the quantitation of microgram quantities of protein utilizing the principle of protein-dye binding. Anal. Biochem., 72, 248-254 (1976).

Chong, F. C., Tan, W. S., Awang Biak, D. R., Ling, T. C., Tey, B. T., Purification of histidine tagged nucleocapsid protein of Nipah virus using immobilised metal affinity chromatography. J. Chr. B., 877, 1561-1567 (2009).

Clemmitt, R. H., Bruce, L. J., Chase, H. A., On-line monitoring of the purification of GST-(His) ${ }_{6}$ from 
an unclarified Escherichia coli homogenate within an immobilised metal affinity expanded bed. Biosep., 874, 27-43 (1999).

Cristancho, C. A. M., David, F., Franco-Lara, E., Seidel-Morgensten, A., Discontinuous and continuous purification of single-chain antibody fragments using immobilised metal ion affinity chromatography. J. Biotechnol., 163, 233-242 (2013).

Dalal, S., Raghava, S., Gupta, M. N., Single-step purification of recombinant green fluorescent protein on expanded beds of immobilized metal affinity chromatography media. Biochem. Eng. J., 42, 3012-307 (2008).

Doukyu, N., Kuwahara, H., Aono, R., Isolation of Paenibacillus illinoisensis that produces cyclodextrin glucanotransferase resistant to organic solvents. Biosci. Biotechnol. Biochem., 2, 334-340 (2003).

Finette, G. M. S., Mao, Q. M., Hearn, M. T. W., Comparative studies on the isothermal characteristics of proteins adsorbed under batch equilibrium conditions to ion-exchange, immobilized metal affinity and dye affinity matrices with different ionic strength and temperature conditions. J. Chr. A., 763, 79-90 (1997).

Foo, K. Y., Hameed, B. H., Insights into the modelling of adsorption isotherm systems. Chem. Eng. J., 156, 2-10 (2010).

Gaberc-Porekar, V., Menart, V., Perspectives of immobilized-metal affinity chromatography. J. Biochem. Biophy. Met., 49, 335-360 (2001).

Goh, K. M., Mahadi, N. M., Hassan, O., Raja Abdul Rahman, R. N. Z., Rosli, M. I., Molecular modeling of a predominant $\beta$-CGTase G1 and analysis of ionic interaction in CGTase. Biotechnol., 3, 418-429 (2008).

Goh, H. P., Illias, R. M., Goh, K. M., Rational mutagenesis of cyclodextrin glucanotransferase at the calcium binding regions for enhancement of thermostability. Int. J. Mol. Sci., 13, 5307-5323 (2012).

Guru, M. M. S., Rajakumari, D. M., Jayashree, S., Fauzia, M., Kumar, D. J. M., Kalaichelvan, P. T., Production and purification of CGTase of alkalophilic Bacillus isolated from Marneri pond in Tirunelveli District, Tamil Nadu. J. Acad. Ind. Res., 2, 101-105 (2012).

Hasar, H., Adsorption of nickel (II) from aqueous solution onto activated carbon prepared from almond husk. J. Hazard. Mat. B. 97, 49-57 (2003).

Hemdan, E. S., Zhao, Y. J., Sulkowski, E. and Porath, J., Surface topography of histidine residues: A facile probe by immobilised metal affinity chro- matography. Proc. Natl. Acad. Sci., USA, 86, 1811-1815 (1989).

Higuti, H. I., Grande, S. W., Sacco, R., Nascimento, A. J., Isolation of alkalophilic CGTase producing bacteria and characterization of cyclodextrin glycosyltransferase. Braz. Arch. Biol. Technol., 46, 183-186 (2003).

Ibrahim, A. S. S., Salamah, A. A. and Antranikian, G., A novel cyclodextrin glycosyltransferase from alkaliphilic Amphibacillus sp. NPST-10: Purification and properties. Int. J. Mol. Sci., 13(8), 10505-10522 (2012).

Kaneko, T., Kato, N., Nakamura, K., Horishoki, K., Spectrophotometric determination of cyclization activity of $\beta$-cyclodextrin-forming cyclomaltodextrin glucanotransferase. J. Jpn. Soc. Star. Sci., 34, 45-48 (1987).

Kozlowski, H., Bal, W., Kasprzak, K. S., Molecular models in nickel carcinogenesis. J. Inorg. Biochem., 79, 213-218 (2000).

Martins, R. F., Kaul, R. H., A new cyclodextrin glucosyltransferase froman alkaliphilc Bacillus agaradhaerens isolate: Purification and characterization. Enzyme Microb. Technol., 30, 116-124 (2002).

Porath, J., Immobilized metal ion affinity chromatography. Prot. Exp. Purif., 32, 263-281 (1992).

Prasanna, R. R., Vijayalakshmi, M. A., Immobilized metal-ion affinity systems for recovery and structure-function studies of proteins at molecular, supramolecular and cellular levels. Pure Appl. Chem., 82, 39-55 (2010).

Qi, Q., Mokhtar, M. N., Zimmermann, W., Effect of ethanol on the synthesis of large-ring cyclodextrin by cyclodextrin glucanotransferases. J. Inclusion Phenom. Macro. Chem., 57, 95-99 (2007).

Rosso, A., Ferrarotti, S., Miranda, M. V., Krymkiewicz, N., Nudel, B. C., Cascone, O., Rapid affinity purification processes for cyclodextrin glycosyltransferase from Bacillus circulans. Biotechnol. Lett., 27, 1171-1175 (2005).

Savergave, L. S., Dhule, S. S., Jogdand, V. V., Nene, S. N., Garde, R., Production and single step purification of cyclodextrin glycosyltransferase from alkalophilic Bacillus firmus by ion exchange chromatography. Biochem. Eng. J., 39, 510-515 (2008).

Sharma, S., Agarwal, G. P., Interactions of proteins with immobilised metal ions: A comparative analysis using various isotherm models. Anal. Biochem., 288, 126-140 (2001).

Shetty, P., Bhat, S., Iyer, J. L., Shenoy, S., Pai, J. S., Satyamoorthy, K., Hydrophobic interaction chromatography on octyl sepharose- An approach for 
one step platform purification of cyclodextrin glucanotransferases. Prep. Biochem. Biotechnol., 41, 350-364 (2011).

Sian, H. K., Said, M., Hassan, O., Kamaruddin, K., Ismail, A. F., Rahman, R. A., Nik Mahmood, N. A., Illias, R. M., Purification and characterization of cyclodextrin glucanotransferase from alkalophilic Bacillus sp. G1. Process Biochem., 40, 1101-1111 (2005).

Sun, X., Chiu, J. F., He, Q. Y., Application of immobilized metal affinity chromatography in proteomics. Expert Rev. Proteomics., 2, 649-657 (2005).

Tsai, S. Y., Lin, S. C., Suen, S. Y., Hsu, W. H., Effect of number of poly (His) tag on the adsorption of engineered proteins on immobilized metal affinity chromatography adsorbents. Process Biochem., 41, 89-95 (2006).

Ueda, E. K., Gout, P. W., Morganti, L., Current and prospective applications of metal ion-protein binding. J. Chr., A, 988, 1-23 (2003).

Vassileva, A., Atanasova, N., Ivanova, V., Dhulster, P., Tonkova, A., Characterization of cyclodextrin glucanotransferase from Bacillus circulans ATCC 21783 in terms of cyclodextrin production. Ann. Microbiol., 57, 609-615 (2007).

Volkova, D. A., Lopatin, S. A., Varlamov, V. P., One-step affinity purification of cyclodextrin glu- canotransferase from Bacillus sp. 1070. Biocatal. 2000, Fund. Appl., 41, 67-69 (2000).

Vunnum, S., Gallant, S. R., Kim, Y. J., Cramer, S. M., Immobilized metal affinity hromatography: Modelling of nonlinear multicomponent equilibrium. Chem. Eng. Sci., 50, 1785- 1803 (1995).

Westra, D. F., Welling, G. W., Koedijk, D. G. A. M., Scheffer, A. J., Hauw, T. T., Welling-Westera, S., Immobilised metal-ion affinity chromatography purification of histidine-tagged recombinant proteins: A wash step with a low concentration of EDTA. J. Chr., B, 760, 129-136 (2001).

Yampayont, P., Iizuka, M., Ito, K., Limpaseni, T., Isolation of cyclodextrin producing thermotolerant Paenibacillus sp. from waste of starch factory and some properties of the cyclodextrin glycosyltransferase. J. Incl. Phenom. Macro. Chem., 56, 203-207 (2006).

Yang, Y. H., Wu, T. T., Suen, S. Y., Lin, S. C., Equilibrium adsorption of poly(His)-tagged proteins on immobilized metal affinity chromatographic adsorbents. Biochem. Eng. J., 54, 1-9 (2011).

Zhang, A., Zhang, C., Warikoo, V., Forstrom, J., Riske, F., A modified IMAC method for the capture of target protein from mammalian cell culture harvest containing metal chelating species. Biotechnol. Bioeng., 109, 747-753 (2011). 